\title{
Transformation of the Socio-economic System and the Implementation of Automation Processes in Terms of Shaping Order and Sustainability Processes
}

\author{
Transformacja technologiczna systemu \\ społeczno-gospodarczego oraz wdrażanie automatyzacji \\ w aspekcie kształtowania ładu i procesów zrównoważenia
}

\author{
Barbara Piontek
}

\author{
WSB Academy, ul. Cieplaka 1C, Dąbrowa Górnicza, Poland \\ E-mail:bempiontek@gmail.com \\ ORCID: 0000-0001-7997-5190
}

\begin{abstract}
This article addresses the topic of technological transformation, which is a challenge for progressing automation and robotization processes. The topic is extremely important in terms of changes in contemporary global reality. On the one hand, changes in production factors, automation and robotization processes, and changes in the labor market give rise to some fears, on the other hand, they can be a chance to build a new socio-economic order based on the pillars of sustainability. This system requires the application of the rules of universal behavior and the recognition of work as value in itself. These rules are an important recommendation and basis for shaping decisions in the sphere of choosing new order and ensuring sustainability, rather than only in consumption.

The article synthesizes existing research, which was the basis for further studies and the following hypothesis has been adopted: automation and robotization processes will result in turbulence on the labor market and in the social sphere.

The key purpose of this article is demonstrate that currently automation and robotization are not the subject of systemic research in the field of shaping the structural order in the economic and social sphere, to develop a scheme of technological transformation and to indicate the need to build a strategy for automation and robotization by states that will ensure strategic order and security.

Today, we need to think what should be done to ensure that automation and robotization, as well as the resulting income, do not push the crowds of society into the sphere of lucky losers. Will the distribution of benefits that automation and robotization give today affect the few or all of us? Will the economy and society based on these processes retain the value of work, and will the profits generated from automation and robotics contribute to prosperity, sustainability and development? Are decision makers ready today to prepare comprehensive solutions? The answer to these questions must be formulated today, because modernity will not pass us by.
\end{abstract}

Key words: technological transformation, automation and robotization, strategic management, sustainability, structural order

\section{Streszczenie}

$\mathrm{W}$ artykule podjęto temat transformacji technologicznej, która jest wyzwaniem dla postępujących procesów automatyzacji i robotyzacji. Temat jest niezwykle istotny z punktu widzenia zmian w czynnikach produkcji. Zachodzące procesy automatyzacji i robotyzacji, zmiany na rynku pracy z jednej strony budzą pewne obawy, z drugiej mogą być szansą na zbudowanie nowego ładu społeczno-gospodarczego opartego na filarach zrównoważenia $i$ trwałości. Wymaga stosowania reguł powszechnego postępowania i uznania pracy za wartość samą w sobie. Reguły te stanowią istotne wskazania i bazę dla kształtowania decyzji w sferze wyboru nowego ładu i zapewnienia zrównoważenia, a nie tylko konsumpcji.

W artykule dokonano syntezy istniejących badań, które stanowiły bazę dla dalszych studiów i przyjęto hipotezę, że procesy automatyzacji oraz robotyzacji będą skutkowały turbulencjami na rynku pracy, a także w sferze społecznej. 
Kluczowym celem niniejszego artykułu jest: wykazanie, że obecnie automatyzacja i robotyzacja nie stanowi przedmiotu badań od strony systemowej w zakresie kształtowania ładu strukturalnego w sferze gospodarczej i społecznej; opracowanie schematu transformacji technologicznej; wskazanie na potrzebę zbudowania strategii automatyzacji i robotyzacji przez państwa, która zapewni ład i bezpieczeństwo strategiczne.

Dzisiaj musimy zastanowić się, co należy uczynić, aby automatyzacja i robotyzacja oraz płynący z nich dochód gwarantowany nie zepchnął rzeszy społeczeństwa w sferę szczęśliwi przegrani. Czy dystrybucja korzyści, jakie dają już dziś automatyzacja i robotyzacja będzie dotyczyć nielicznych, czy też nas wszystkich? Czy gospodarka i społeczeństwo oparte na tych procesach zachowa wartość pracy, a zyski wypracowywane z procesów automatyzacji i robotyzacji przyczynią się do budowania dobrobytu, procesów zrównoważenia i rozwoju? Czy decydenci są dziś gotowi na przygotowanie kompleksowych rozwiązań? Odpowiedź na te pytania musimy sformułować już dziś, bo nowoczesność nas nie ominie.

Słowa kluczowe: transformacja technologiczna, automatyzacja i robotyzacja, zarządzanie strategiczne, zrównoważoność, porządek strukturalny

\section{Automation and robotization in management literature and the state of the Polish economy compared to global trends}

The relevant literature lacks theoretical solutions for creating system solutions for the automation and robotization of the economy. Automation and robotization issues mainly focus on technological issues and address processes pertaining to automation and robotization in companies. The discussion related to shaping corporate strategies based on automation has been a challenge for researchers for many years, in terms of competence (Meyer, N Dean, 1986) and exploring the automation and augmentation concepts in the management domain. Whereas automation implies that machines take over a human task, augmentation means that humans collaborate closely with machines to perform a task (Raisch S., Krakowski, 2020), and the automation of a business process as a key factor enables the improvement of business processes (Scheer at al., 2004). It is also important that, from the perspective of system approaches, the attempts in this context were already made by earlier authors. For example, R. W. Coombs considers the role played by technological innovation in the theoretical frameworks found in the literature on long waves. He highlights that some writers place emphasis on consumer good innovations, some on capital good innovations, some on new technologies which affect consumer and capital goods, while others take no view on the relative roles of consumer and capital goods innovations. It is suggested - in his opinion - that capital goods innovations embodying automation may have been important in the mechanism of the current long wave. Data on employment, rates of return, and value-added for the engineering industries lend support to the view that expectations and propensity to innovate may have been high in the capital goods sector before the upswing of the current long wave in economy (Coombs, 1981, pp. 360370). In 1994, B. Carlsson and St. Jacobsson argued in their work that technological systems constitute a useful unit of analysis for not only innovation and diffusion studies but also work related to technology policy. In the case of Sweden's technological system for factory automation (e.g. robots), it is suggested that three features are central to explaining the ex- tensive diffusion of new technology in the Swedish engineering industry, namely bridging institutions, user-supplier linkages, and critical mass coupled to advanced economic competence among a key set of users. As regards public policy, they argued that its role is to facilitate the formation of new technological systems and to enhance the functioning of existing systems rather than to rectify individual market failures. This can be done by creating or strengthening bridging institutions and centers of excellence, promoting speedy and wide diffusion of engineering competence, and strengthening compensating mechanisms (Carlsson, Jacobsson 1994).

R. Abbot and B. Bogenschneider point to the crucial problem of the taxation on automation and robotization. First of all, they emphasize that the problem of taxation on automation is ignored in the debate. Firstly, it is even more concerning that automation significantly reduces the government's tax revenue since most tax revenue comes from labor income. Secondly, they put attention to the fact that the current taxation system encourages automation by providing employers with preferential tax treatment for robot workers. Automation allows firms to avoid employee and employer wage taxes levied by Federal, state, and local taxing authorities. It also permits firms to claim accelerated tax depreciation on capital costs for automated workers, and it creates a variety of indirect incentives for machine workers. All of this is the unintended result of a tax system designed to tax labor rather than capital. Tax policies may thus result in automation in some cases in which a company would otherwise choose a human worker (Abbot, Bogenschneider 2017). The authors have suggested that experts are widely predicting that automation is going to have a substantial impact on employment even in the near term. Bank of America Merrill Lynch argues that by 2025, AI may eliminate $\$ 9$ trillion in employment costs by automating knowledge work. A report by the World Economic Forum estimates that automation could result in the net loss of 5.1 million jobs by 2020. The consulting companies Deloitte claims that 35 percent of jobs in the United Kingdom are at high risk of redundancy due to automation in the next 10 it's 20 years. The McKinsey Global Institute has stated that 51 percent of existing work activities could be automated using 
existing technologies. This is due to a combination of factors: improvements in automation technologies, decreased costs for such technologies, and increased labor costs. Whereas it was previously possible to automate a large number of work processes, it has now become practicable. As automation technologies continue to both improve and decrease in cost, it is difficult to think of work functions that will not eventually be susceptible to automation (Abbot, Bogenschneider 2017, pp. 8-9).

The International Federation of Robotics IFR indicates that the sale of robots in global markets maintains an upward trend and more and more companies are recognizing their benefits from the implementation of robotization and automation, especially in the face of crises, related either to the situation on the labor market or economic crises, or severe crises caused by the result of a pandemic. In 2018, compared to the previous year, the sales of industrial robots in the world increased by $6 \%$ and amounted to 422 thousand units, while in Europe it increased by as much as $14 \%$ to 75,560 units, setting a new record for the sixth year in a row. IFR analysts predict that global growth will continue; it is estimated that from 2020 to 2022, nearly 2 million new industrial robots will be located in companies around the world (World Robotic Report, 2019, pp. 13-16).

According to data from 2018, 5 countries are responsible for $3 / 4$ new installations, i.e. China, Japan, the USA as well as South Korea and Germany. China is the world leader in robotization, with over a third of the global market, despite a 1\% decline in 2018 . 154,000 units sold per year is more than the total number of robots sold in Europe and the Americas. Japan is second at the rate of robotization in the world with a result of 55,000 more machines in 2018 (an increase of 21\%). The United States is in third place: 40.3 thousand units sold and $22 \%$ increase. South Korea occupies fourth place (38 thousand units) and Germany is in fifth place with 27,000 units, making it the largest European robotics market In Poland, despite the $4.5 \%$ increase in GDP, increased minimum wage that everybody enjoys, the rising level of consumption, automation and robotization differ from global standards and indicators. According to the data from the World Robotics 2018 IFR report, the average density of robots in the world is 99 units per 10,000 employees, in Europe 114 units, and in Poland we have only 42 (see Figure 1). Poland occupied the 16 th place in the world ranking, with 13,632 devices installed.

The fundamental indicator which measures the degree of automation and robotization is the average density of robotization, which is measured by the number of industrial robots per 10,000 employees. Figure 1 shows the density of robotization in Poland in 2016-2018 in relation to the total industry, the automotive industry and other industries. The data show that only the automotive industry has a higher density of robotization, while in industry in general, this indicator is more than $50 \%$ lower than the average density of robots in the world.

Figure 1. Density of robotization in Poland, source: https://automatykaonline.pl/, based on the International Federation of Robotics - IFR

Number of robots per 10000 employees

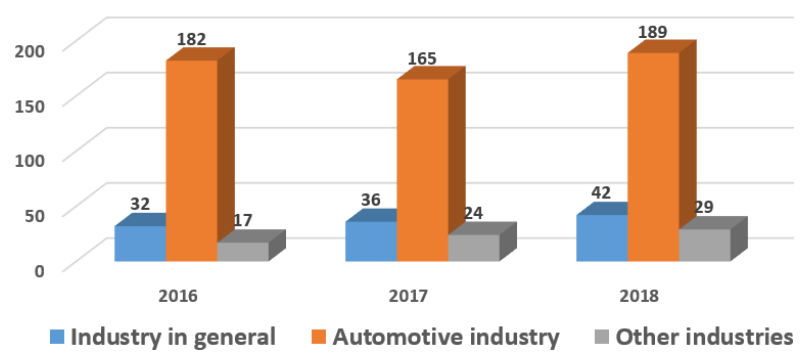

Compared to our region of Europe, the level of automation of the Polish economy is also the lowest (see Figure 2). The domestic market has been growing more dynamically since 2014 (at least 1,000 industrial robots installed each year), but the number of installations is still insufficient to catch up with the Czech Republic or Slovakia.

Figure 2. Density of robotization - Poland compared to other countries in the region, average density in Europe is 144, source: https://automatykaonline.pl based on the International Robotics Federation - Raport-IFR-World-Robotics-2019

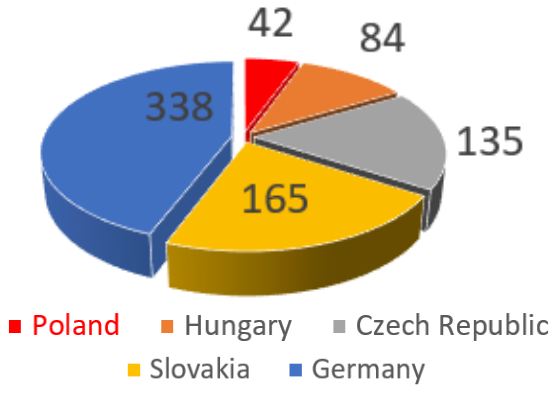

At the same time, the interest of Polish entrepreneurs in the introduction of robotization is still insufficient. The 2018 Work Service research entitled The attitude of employers to work automation shows that only a quarter of companies in Poland want to invest in work automation. Nevertheless, the plans of these companies are defined neither as to the dates nor the scale (see Figure 3).

Research results in individual industries are presented in Figure 4. Data show clearly that in the public sector in Poland only $10 \%$ of respondents are interested in automation and robotization. Such a low number certainly implies even lower implementation, so one can certainly conclude that the public sphere is not in the least prepared for real improvement in efficiency and effectiveness in the near future.

The research also shows that if the company is already planning to implement automation, they do it first of all to increase quality, competitiveness and 
Figure 3. Attitude of companies to automation in Poland, source: ccnews.pl

Our company is not interested in automation

We are interested in automation, but now we are not planning to implement it

Automation has a huge impact and the potential for my company and we are implementing it

Automation has a huge impact and the potential for my company and we are planning to implement it

I don't know, it is hard to say

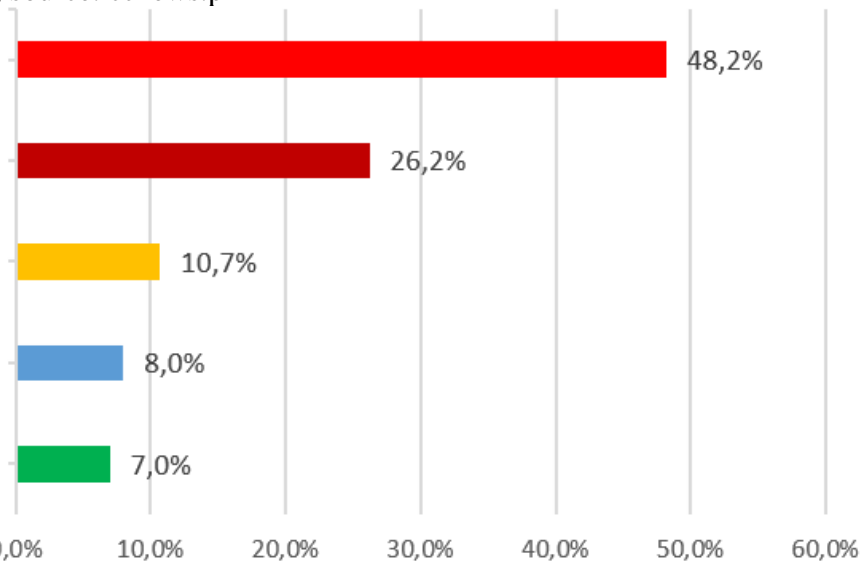

Figure 4. Attitude of companies in Poland to automation by industry, Source: Research conducted by Kantar Millward Brown, ccnews.pl

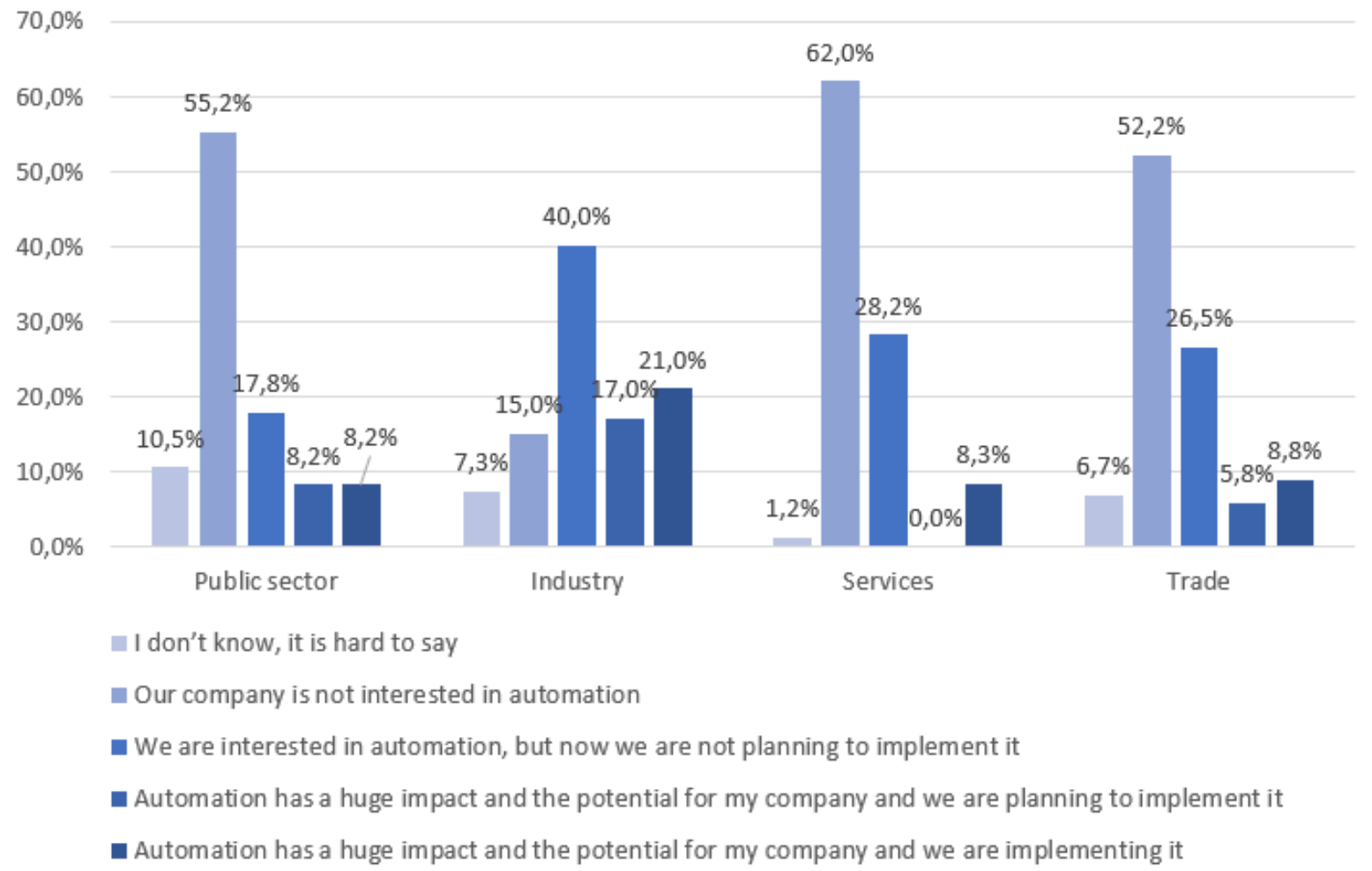

efficiency $-79.75 \%$ of companies, to increase employee safety and comfort $(76.3 \%)$, to reduce costs $(71.7 \%$, ) and only $57.2 \%$ to reduce staff shortages. In the decision-making process, Polish entrepreneurs most rarely take low unemployment and population decline into account. Meanwhile, the forecasts of the Central Statistical Office seem relentless. By 2050, the Polish population is expected to decrease from 38 million to 34 million people. This means a smaller population size by $1 / 9$, in some regions this decrease may amount to even 30\% (Raport, 2014). Fewer Poles simply mean fewer and fewer staff available on the labor market.

Raising the rates of robotization and automation can be the key to the development of many countries, to get out of the middle income trap and to truly improve the quality of life.

Economies and societies are at a time when an attitude to automation and robotization must be addressed in a systemic way and requires a strategic approach. Today, robotization and automation processes create a need to build new socio-economic systems. Automation and robotization cannot be a goal in itself, but only a tool which enables the implementation of correctly defined priorities. They aim to contribute to increased efficiency and effectiveness while improving the quality of life and shaping the right relationship between have and $b e$. Building a new socio-economic system based on the processes of automation and robotization requires 
the application of the rules of universal procedures, understood as norms which determine and verify the procedures used, and the recognition of work as value in itself. Failure to take these actions will result in strengthening inequalities between the owners of technology (automation and robotization) and others in personal and institutional terms (i.e. states and societies).

\section{Methodology}

In order to effectively and objectively achieve research objectives, descriptive analysis and critical analysis methodology and a deductive method were adopted. The reason for using the deductive approach is that it allows for the determination of directions for shaping management policy and setting priorities. It becomes a verifier for the real sphere. P. Sulmicki (Sulmicki, 1973, p. 9) puts it in a synthetic way: there is nothing better for practice than a good theory. It allows you to answer the question of how it should be, and the process of collecting and analyzing data verified in relation to theory and only then is it subject to detailed and subjective modifications. Deduction-based methodology allows you to design the future and set priorities correctly. This is especially important for public management.

This methodology included primary and secondary sources for collecting relevant data and is the result of available research in this area. It included studies on automation and robotization, strategic management, sustainability, structural order, and strategic management in the public sphere.

\section{Conducting theoretical research and practi- cal solutions for strategic management}

\subsection{The category of the structural order and sustain-} ability and the concept of development

There are a number of relationships between ensuring the structural order, sustainability and the concept of development. The core category is the structural order. It is a positive goal of developmental changes, an outcome which combines, in a consistent way, economic, social (including institutional and political) and environmental (including spatial) order. Therefore, the system of strategic environmental goals, and the goals of socio-economic development and spatial development creates a structural basis for shaping the integrated order (Borys, 2011). In other words, it is a state of order and harmony that permeates all areas of human activity as seen from economic, social, environmental and institutional perspectives, as well as in the broadly defined nonmaterial dimension. The achievement of the structural order means the practical implementation and application of constituent axioms, natural law and superior values in the economic and social spheres of human activity. To put it simply, this means ob- jective control and application of fundamental ethical principles in broadly defined management which are inherent in natural law. They determine the achievement of the economic order as well as international, moral, social and political order (Piontek, 2009). The structural order understood in this way is directly related to the category of sustainability. This category is related to the concept of development, which is sustainable development.

Sustainable development as a category does not have one definition. For example, in the article (B. Piontek, 2002), 44 definitions of this category were identified. This article adopts the definition of F. Piontek, which says that sustainable development is shaping the right proportions between the three types of capital (E: H: N) of present and future generations. The concept understood in this way can be considered in both subjective and objective terms. It is also important that sustainable development is not only an intellectual concept, but it can be implemented, for example, in public management at the central and local government levels, also in territorial systems (for example, by implementing the objectives contained in central policies and strategies at the regional level), which has its justification in art. 5 of the Constitution of the Republic of Poland. It should also be noted that the subjective approach does not and should not exclude the objective approach, including the one based on automation and robotization processes. This approach defines both formal and informal objects.

In the relevant literature, a homogeneous approach is usually applied to the concept of sustainable development, assuming that this is one concept. This approach is logically debatable, for example because of the multitude of definitions of the category itself. Practice also proves that in various conditions the assumptions of this concept can be implemented through a series of detailed concepts, equivalent to the fundamental assumptions of this concept, the integrating feature of which is sustainability. Therefore, it seems justified to treat two sets of concepts based on sustainability and unsustainability processes.

The core decision is to choose between a concept selected from a set of concepts based on sustainability processes and a concept selected from a set of concepts based on unsustainability processes.

Detailed attributes which diversify the sets of the concepts of development based on sustainability processes and unsustainability processes are discussed in the work (Piontek F., Piontek B., 2017):

In the set of sustainable concepts, a concept of sustainable development should be mentioned as a representative of this set. This is justified by the international commitment to work on this concept. Regardless of this, it should be pointed out that the set of concepts based on sustainability processes also includes other concepts, e.g. ordoliberalism, the social market economy and many options of their imple- 
Table 1: Attributes that differentiate a set of concepts based on sustainability and unsustainability processes in relation to automation and robotization Source: Own study

\begin{tabular}{|c|c|c|c|}
\hline No. & $\begin{array}{l}\text { Differences that distinguish a set of concepts } \\
\text { based on sustainability processes from a set of } \\
\text { concepts based on unsustainability processes }\end{array}$ & $\begin{array}{l}\text { Automation and robotization } \\
\text { as a factor which shapes sus- } \\
\text { tainability processes }\end{array}$ & $\begin{array}{l}\text { Automation and robotization } \\
\text { as a factor which shapes un- } \\
\text { sustainability processes }\end{array}$ \\
\hline 1. & $\begin{array}{l}\text { Embedding the concept of development on } \\
\text { norms, natural law and superior values, rather } \\
\text { than on paradigms that are relative and criterion- } \\
\text { based. }\end{array}$ & $\begin{array}{l}\text { A criterion which verifies the } \\
\text { processes of automation and ro- } \\
\text { botization is norms, natural law } \\
\text { and superior values }\end{array}$ & $\begin{array}{l}\text { A criterion which verifies the } \\
\text { processes of automation and ro- } \\
\text { botization is paradigms }\end{array}$ \\
\hline 2. & $\begin{array}{l}\text { An attitude to the types of capital: taking three } \\
\text { fundamental types of capital (economic, human } \\
\text { and natural) into account. }\end{array}$ & $\begin{array}{l}\text { Shaping the proportion be- } \\
\text { tween three types of capital: E: } \\
\text { H: N }\end{array}$ & $\begin{array}{l}\text { Subordinating the processes of } \\
\text { multiplying economic capital }\end{array}$ \\
\hline 3. & $\begin{array}{l}\text { The growth process treated as a component of } \\
\text { the development process, subordinated to devel- } \\
\text { opment rather than an independent category, the } \\
\text { result of which may be development, but also } \\
\text { inequalities. }\end{array}$ & $\begin{array}{l}\text { Growth process subordinated to } \\
\text { the development process }\end{array}$ & Permanent growth \\
\hline 4. & $\begin{array}{l}\text { Shaping the relationship between the types of } \\
\text { capital - one cannot develop or grow at the ex- } \\
\text { pense of the other. }\end{array}$ & $\begin{array}{l}\text { One cannot grow at the ex- } \\
\text { pense of the other }\end{array}$ & $\begin{array}{l}\text { It is allowed that one develops } \\
\text { at the expense of the other }\end{array}$ \\
\hline 5 . & Strategic planning. & $\begin{array}{l}\text { Obligatory strategic planning. } \\
\text { Long-term dimension }\end{array}$ & $\begin{array}{l}\text { Technological usability be- } \\
\text { comes a time period of plan- } \\
\text { ning }\end{array}$ \\
\hline 6. & $\begin{array}{l}\text { The determination and development of strategic } \\
\text { areas and industries. }\end{array}$ & $\begin{array}{l}\text { Determined and related to auto- } \\
\text { mation and robotization. They } \\
\text { are designed to ensure strategic } \\
\text { security }\end{array}$ & None \\
\hline 7. & $\begin{array}{l}\text { The correct understanding of the category of ef- } \\
\text { ficiency and its use in accordance with or con- } \\
\text { trary to the nature of the entities and phenomena } \\
\text { assessed. }\end{array}$ & $\begin{array}{l}\text { Processes that take economic, } \\
\text { social and environmental effi- } \\
\text { ciency into account. }\end{array}$ & $\begin{array}{l}\text { Processes subordinated to eco- } \\
\text { nomic efficiency }\end{array}$ \\
\hline 8. & $\begin{array}{l}\text { The use of measures for measuring both the de- } \\
\text { velopment and growth processes }\end{array}$ & $\begin{array}{l}\text { Quantitative and qualitative } \\
\text { measures }\end{array}$ & Quantitative measures \\
\hline 9. & $\begin{array}{l}\text { The observance of appropriate relationships in } \\
\text { processes between the speed of change in eco- } \\
\text { nomic and non-economic figures while respect- } \\
\text { ing quality parameters. }\end{array}$ & $\begin{array}{l}\text { The pace of processes subordi- } \\
\text { nated to sustainability and qual- } \\
\text { ity }\end{array}$ & $\begin{array}{l}\text { The pace of processes focused } \\
\text { on permanent growth }\end{array}$ \\
\hline 10. & $\begin{array}{l}\text { Managing demand and supply as core areas for } \\
\text { the implementation of selected concepts and } \\
\text { adopted strategies. }\end{array}$ & $\begin{array}{l}\text { Protection of domestic demand } \\
\text { and supply which guarantees } \\
\text { strategic security }\end{array}$ & Global demand and supply \\
\hline 11. & $\begin{array}{l}\text { A choice between an external concept or a bot- } \\
\text { tom-up concept. }\end{array}$ & $\begin{array}{l}\text { A bottom-up concept which } \\
\text { takes the internal potential into } \\
\text { account. }\end{array}$ & $\begin{array}{l}\text { Concepts adopted for the short- } \\
\text { term use }\end{array}$ \\
\hline 12. & $\begin{array}{l}\text { A choice between a diffusion-polarizing model } \\
\text { and a sustainable model }\end{array}$ & Sustainable model & Diffusion-polarizing model \\
\hline 13. & $\begin{array}{l}\text { Proportions between the sovereignty and integra- } \\
\text { tion of a country or region in the economic, social } \\
\text { and institutional terms. }\end{array}$ & $\begin{array}{l}\text { Proportions between the sover- } \\
\text { eignty and integration of a } \\
\text { country or region in the eco- } \\
\text { nomic, social and institutional } \\
\text { terms. }\end{array}$ & $\begin{array}{l}\text { Integration used to maximize } \\
\text { flow and build value chains }\end{array}$ \\
\hline 14. & Equalling territorial opportunities. & $\begin{array}{l}\text { Territorial development de- } \\
\text { pends on the level of automa- } \\
\text { tion and robotization in a given } \\
\text { area. The distribution of bene- } \\
\text { fits related to the long-term } \\
\text { plan and the functionality of } \\
\text { strategic areas }\end{array}$ & $\begin{array}{l}\text { Territorial development de- } \\
\text { pends on the level of automa- } \\
\text { tion and robotization in a given } \\
\text { area. }\end{array}$ \\
\hline 15. & $\begin{array}{l}\text { Creating highly specialized jobs instead of cheap } \\
\text { labor }\end{array}$ & $\begin{array}{l}\text { Yes. A labor market which } \\
\text { takes the structural order into } \\
\text { account. Income guaranteed by } \\
\text { a component of remuneration } \\
\text { resulting from the adopted dis- } \\
\text { tribution model }\end{array}$ & $\begin{array}{l}\text { Yes. A labor market shaped by } \\
\text { the guaranteed income model }\end{array}$ \\
\hline
\end{tabular}




\begin{tabular}{|c|c|c|c|}
\hline No. & $\begin{array}{l}\text { Differences that distinguish a set of concepts } \\
\text { based on sustainability processes from a set of } \\
\text { concepts based on unsustainability processes }\end{array}$ & $\begin{array}{l}\text { Automation and robotization } \\
\text { as a factor which shapes sus- } \\
\text { tainability processes }\end{array}$ & $\begin{array}{l}\text { Automation and robotization } \\
\text { as a factor which shapes un- } \\
\text { sustainability processes }\end{array}$ \\
\hline 16. & Criteria for environmental assessment & $\begin{array}{l}\text { Coherence and correctly de- } \\
\text { fined subordination to develop- } \\
\text { ment. } \\
\text { Created models which ensure } \\
\text { the internalization of environ- } \\
\text { mental costs }\end{array}$ & $\begin{array}{l}\text { Subordinated to efficiency and } \\
\text { growth. } \\
\text { Pro-environmental models sub- } \\
\text { ordinated to efficiency, the im- } \\
\text { plemented model of shifting } \\
\text { environmental costs to the en- } \\
\text { vironment and in time }\end{array}$ \\
\hline 17. & $\begin{array}{l}\text { Supporting industry education and building solu- } \\
\text { tions aimed at developing the combination of ed- } \\
\text { ucation and practice. }\end{array}$ & $\begin{array}{l}\text { Providing highly qualified staff } \\
\text { to support automation and ro- } \\
\text { botization processes. Science } \\
\text { understood as sofia and techne. }\end{array}$ & $\begin{array}{l}\text { Providing highly qualified staff } \\
\text { for servicing automation and } \\
\text { robotization processes. } \\
\text { Science limited to techne }\end{array}$ \\
\hline 18. & Support for socially excluded areas. & $\begin{array}{l}\text { Starting development processes } \\
\text { in excluded areas. }\end{array}$ & $\begin{array}{l}\text { The consolidation of the pro- } \\
\text { cesses of technological stratifi- } \\
\text { cation }\end{array}$ \\
\hline 19. & An attitude to the category of work & $\begin{array}{l}\text { Work as a value. Ensuring ac- } \\
\text { cess to work for everyone. }\end{array}$ & $\begin{array}{l}\text { Work as an element of servic- } \\
\text { ing automation and robotiza- } \\
\text { tion processes. Work as a privi- } \\
\text { lege, rather than a necessity. } \\
\text { Access to work - limited }\end{array}$ \\
\hline 20. & $\begin{array}{l}\text { Adoption of the model of benefit distribution re- } \\
\text { sulting from automation and robotization pro- } \\
\text { cesses. }\end{array}$ & $\begin{array}{l}\text { The distribution of benefits re- } \\
\text { sulting from automation and ro- } \\
\text { botization in society. }\end{array}$ & $\begin{array}{l}\text { The accumulation of benefits } \\
\text { for the few }\end{array}$ \\
\hline 21. & The increased quality of life & $\begin{array}{l}\text { The increased quality of life } \\
\text { proportionally to the adopted } \\
\text { model of benefit distribution. } \\
\text { The new structural order ensur- } \\
\text { ing access and quality of life of } \\
\text { society. }\end{array}$ & $\begin{array}{l}\text { Increased quality of life propor- } \\
\text { tionally to the adopted model } \\
\text { of benefit distribution. }\end{array}$ \\
\hline 22. & Consumption model & $\begin{array}{l}\text { Change in the consumption } \\
\text { model from a quantitative to a } \\
\text { qualitative model. Consump- } \\
\text { tion based on qualitative crite- } \\
\text { ria }\end{array}$ & $\begin{array}{l}\text { Ensuring the right to consume. } \\
\text { Consumption based on quanti- } \\
\text { tative criteria }\end{array}$ \\
\hline
\end{tabular}

mentation, which satisfy the sustainability criteria. However, there are also a number of solutions that, despite similar names, do not meet the sustainability criteria, are ostensible and sometimes contradictory. Unsustainability offers the possibility of creating more, also ostensible concepts. Automation and robotization processes will also significantly contribute to the preservation of specific sets.

The choice between concepts based on sustainability or unsustainability processes seems to be obvious and easy. It should be noted, however, that sustainability alone is not a sufficient condition to ensure the order. Ensuring the order lies in decisions, and their correctness should be shaped in accordance with the sense and purpose of human existence and action.

For the purposes of this article, basic differences between the set of concepts based on sustainability processes and the set of concepts based on unsustainability processes should be discussed in a synthetic way, and these include:

- embedding the concept of development on norms, natural law and superior values rather than on paradigms, which are relative and criterion-based;
- $\quad$ an attitude to capital - taking three basic types capital, i.e. economic, human and natural into account, with the supremacy of human capital;

- the growth process treated as a component of the development process, subordinated to development rather than an independent category, the result of which may be development but also inequalities;

- the ways of managing individual types of capitals, shaping relationships between the types of capital - one cannot develop or grow at the expense of the other;

- $\quad$ taking quantitative and qualitative criteria into account;

- $\quad$ strategic planning or its appearances;

- the determination and development of strategic areas and industries;

- the correct understanding of the category of efficiency and its use in accordance with or contrary to the nature of the entities and phenomena being assessed;

- the use of measures for measuring both the development and growth processes;

- the observance of appropriate relationships between the pace of change in economic and non- 
economic figures while respecting quality parameters;

- the management of demand and supply as the core areas for the implementation of selected concepts and adopted strategies;

- a choice between an external concept or a bottom-up concept;

- $\quad$ a choice between a diffusion-polarizing model and a sustainable model;

- a choice between the sovereignty and integration of the country or region in the economic, social and institutional terms;

- $\quad$ an attitude to the category of work;

- the adoption of a model of benefit distribution resulting from automation and robotization processes.

To put it simply, it can be assumed that the choice between concepts from the sets of:

1) concepts based on sustainability processes or

2) concepts based on unsustainability processes is crucial for shaping the order and sustainability during the implementation of automation and robotization processes in the operational and conceptual dimensions.

\subsubsection{Automation and robotization as a factor of shaping the structural order}

Taking into account the attributes that distinguish the set of concepts based on sustainability and unsustainability processes in Table 1 , the form that these attributes can take and the formula they can be used in when applying automation and robotization have been described. In this context, 21 attributes have been identified, but it should be noted that this is not a closed set and can be specified. It is important that the adoption of specific solutions in real terms depends on the state's efficiency in responding to challenges posed by contemporary reality in the area of strategic planning.

The analysis in Table 1 shows that automation and robotization can implement both sustainability and unsustainability processes in real terms. They are a production factor that will have a key impact on the condition of economies and countries. It depends on the institutions responsible for development which processes will be implemented based on automation and robotization.

\subsection{Technological transformation of the economic and social system - challenges and recommen- dations}

Technological transformation is a process of socioeconomic changes shaped by a factor of change, that is the processes of automation and robotization, determined by the choice of the concept of development and the resulting attributes and subject to criterion assessment, which allows for the definition of the sense and purpose of existence and action, on the basis of which a new structural order and quality of life are shaped. The key element here is the factor of change, which includes automation and robotization. It is important that this valuable factor is determined by the choice of the concept of development and can implement both sustainability and unsustainability processes in real terms. This choice is the autonomous choice of decision makers. It cannot be imposed, usually the public authority makes such a choice with a democratic mandate.

The factor of change, which is automation and robotization, touches on a number of structural, systemic, planning, tool, institutional, organizational changes, etc. It requires building a model of benefit distribution resulting from automation and robotization associated with the concept of development. In addition, it requires the creation of two system areas: the taxation system of automation and robotization, and the remuneration system, the component of which would be an addition from automation and robotization.

Revenues generated from the taxation of process robotization and automation can be fed into the income stream. Workplaces which shrink in some areas can be created in others by increasing efficiency in automated processes, for example by reducing the exploitation of today's employee, whose working week does not have to last 40 hours in a five-day working week, but e.g. 20 hours in a four-day working week. Thus, providing round-the-clock production or service support can generate up to six full-time jobs, not three. Financial participation in the remuneration should be provided from funds obtained from the taxation of automation and robotization, and the correct distribution of these funds. Such a solution will increase the efficiency of these employees, will not be a burden to the employer, and at the same time will create new jobs, improve the quality of life and ensure the structural order.

As regards the importance of the state and the implementation of sustainability processes in shaping the new socio-economic system with the use of automation and robotization processes, the following strategic actions are crucial:

- defining the tasks of the state as a generator and entity which finances main research;

- formulating strategic areas in the economy based on automation and robotization processes;

- creating system solutions for the broadly defined business sphere;

- developing a long-term plan for the national economy and transferring this area for development through short-term activities in business areas, in particular in the area of state-owned companies;

- developing a long-term plan for human capital, both in the area of shaping the labor market and - perhaps above all - in the area of knowledge and education, educational models and connections with the new socio-economic model; 
Diagram 1. Diagram of the technological transformation, source: own study

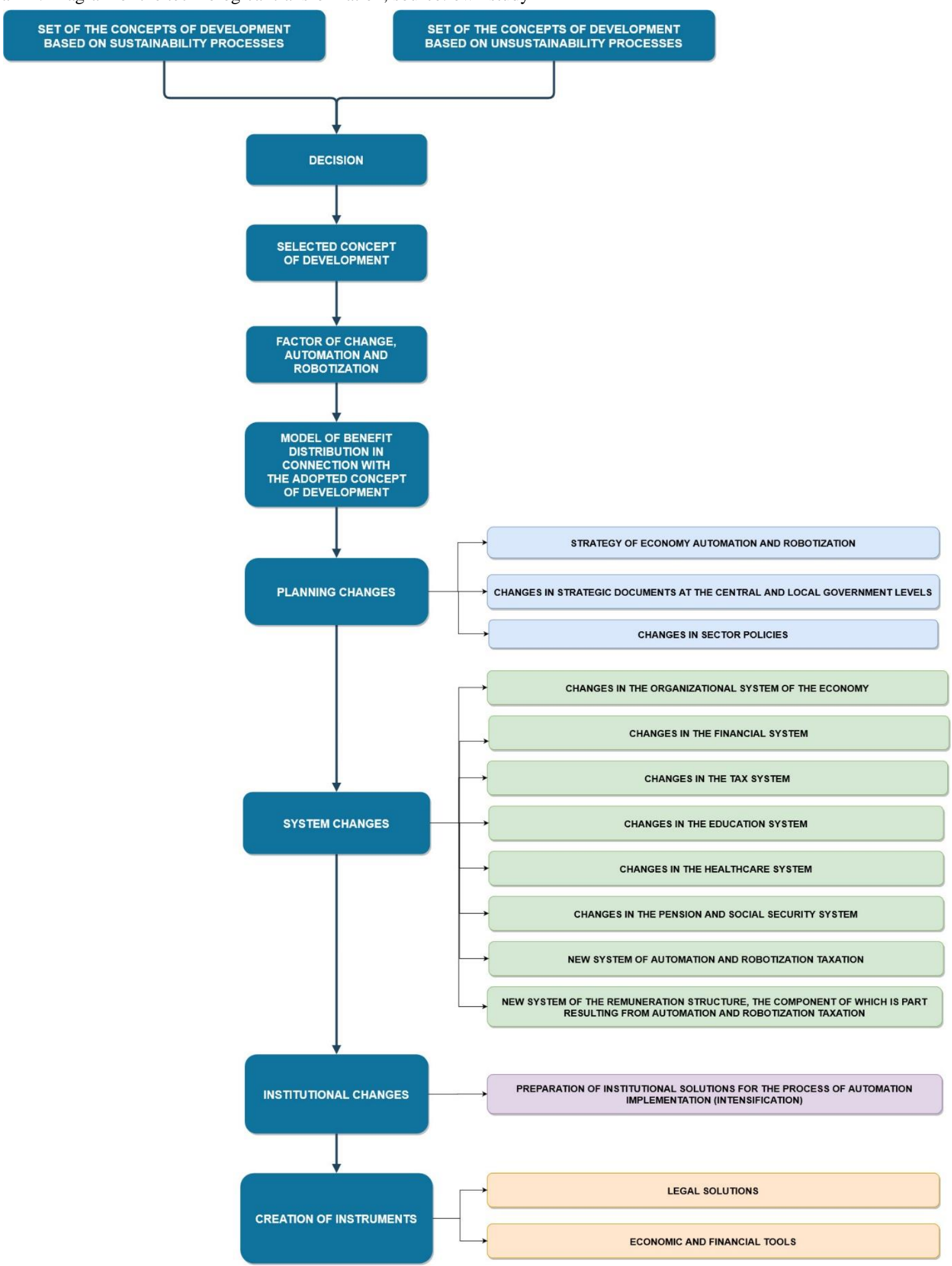

- fair and responsible distribution of the benefits of automation and robotization in the social structure;
- $\quad$ linking the area of knowledge and education with the processes of automation and robotization to shape order on the labor market; 
- $\quad$ opening up financing possibilities for automation and robotization processes;

- $\quad$ identifying crucial areas that will be subject to full automation, indirect automation, non-automated areas and areas protected against automation and robotization;

- laying the foundations for a new fiscal and tax system;

- developing social security solutions regarding guaranteed income and working time;

- preparing solutions for the pension and healthcare system;

- $\quad$ planning rules for the distribution of benefits between automated areas and areas that will not be automated;

- developing instruments to implement these processes in real terms;

- $\quad$ preparing legal solutions;

- developing solutions for increasing the implementation of automation and robotization processes in three areas:

1) public,

2) companies with the State Treasury participation,

3) private business.

The subsequent step is to build an education strategy based on these areas that will take the absorbency of individual areas of the economy for human resources into account.

The crucial area for the new socio-economic system using automation and robotization processes is the area of science and education, which will soon have to fulfill the requirements of the technology market. F. Piontek pays attention to the current trend: science changes its nature, there is a systematic departure from the sphere of sofia (wisdom) to the sphere of techné (skill). Meanwhile, the technology market based on automation and robotization processes is demanding. First of all, it needs the departure from narrowly understood specializations in favor of interdisciplinarity. Education in this field is not only a challenge, but above all a duty. It depends on decision-makers whether bureaucracy, obsession with grants and points become the main barrier to creating science and sofia (wisdom) as a base for education for the needs of a demanding technology market. The paradox of the technological economy is that it requires education in the general areas of science (including interdisciplinary areas, focused on quality based on logic, philosophy, the application of the rules of universal procedures and social competences), rather than, as is commonly believed, greater technical development in science and educational processes. Making mistakes in this area is irreversible, very expensive and can constitute a barrier on the Polish path to the development of the economy based on automation and robotization with features of innovation. Innovation cannot be officially programmed, it is a feature that is the result of a number of variables and requires a lot of investment. Short- term education, so-called crisis education, patching holes in the labor market with education can be a road to nowhere. The strategy as a forward-looking document should definitely take into account the answers to the question about what should be done so that automation and robotization as well as the resulting guaranteed income do not push the crowds of society into the sphere of lucky losers. How can the process be conducted so that the benefits that automation and robotization already give today are distributed not only to the few but to all of us? How can the economy and society based on these processes preserve the value of work and the profits generated from automation and robotization processes contribute to prosperity, sustainability and development?

\section{Conclusion}

Modernity - and thus the processes of automation and robotization - can be compared to the element. We will not run away from them, anyway running would do nothing. When uncontrollable, however, these processes can be fraught with consequences. The important thing is that they are morally neutral in themselves, and are neither good nor bad. It depends on us whether and how we program them and in whose interest. Today, we need to think what should be done to ensure that automation and robotization, as well as the resulting income, do not push the crowds of society into the sphere of lucky losers. Will the distribution of benefits that automation and robotization give today affect the few or all of us? Will the economy and society based on these processes retain the value of work, and will the profits generated from automation and robotization contribute to prosperity, sustainability and development? Are decision makers ready today to prepare comprehensive solutions? The answer to these questions must be formulated today, because modernity will not pass us by.

Change in the policy of states will enable the integration of already existing, but very dispersed solutions regarding the implementation of automation and robotization processes described in government policies, sectoral strategies and undertaken in many initiatives. On the other hand, it will enable sovereignty, which in the face of contemporary crisis will become a priority and will be an opportunity to take targeted actions that will allow for the proper distribution of benefits and the development of sustainable processes.

\section{References}

1. ABBOT R., BOGENSCHNEIDER B., 2017, Should Robots Pay Taxes? Tax Policy in the Age of Automation, 12, in: Harvard Law \& Policy Review, 12.

2. BORYS T., 2011, Zrównoważony rozwój - jak rozpoznać ład zintegrowany, in: Problemy Ekorozwoju/ Problems of Sustainable Development, 6(2), p. 75-81. 
3. CARLSSON B., JACOBSSON S., 1994, Technological systems and economic policy: the diffusion of factory automation in Sweden, in: Research Policy, 23(3), p. 235-248.

4. COOMBS R. W., 1981, Innovation, automation and the long-wave theory, in: Futures, 13(5), p. 360-370.

5. Automatyka Online, 2020, https://automatykaonline. $\mathrm{pl} /$.

6. INIERNATIONAL FEDERATION OR ROBOTICS， 2018, World Robotics Report, https://ifr.org/ downloads/press2018/Executive_Summary_WR_20 18_Industrial_Robots.pdf.

7. KANTAR MILLWARD BROWN, Attitude of companies in Poland to automation by industry, htpps://ccnews.pl.

8. MEYER N.D., 1983, The Office Automation Cookbook: Management Strategies for Getting Office $\mathrm{Au}-$ tomation Moving, in: Sloan Management Review, Cambridge, 51.

9. PIONTEK B.,2002, Koncepcja rozwoju zrównoważonego i trwatego Polski, PWN, Warszawa.

10. PIONTEK B., PIONTEK F., 2017, Development from Theory to Practice, Shaker Verlag, Aachen.

11. PIONTEK F., 2009, Aksjomat 'Człowiek najwyższą wartościa w świecie przyrody' podstawa ładu strukturalnego i ładu w nauce, in: Nierówności społeczne a wzrost gospodarczy. Uwarunkowania instytucjo-
12. nalne, 14, ed. Woźniak M.G., Uniwersytet Rzeszowski, Rzeszów.

13. PIONTEK B., 2019, The theoretical basis of strategic security management for shaping the structural order and sustainability processes, in: Polish Journal of Management Studies. 20(1).

14. RAISCH S., KRAKOWSKI S., 2020, Artificial Intelligence and Management: The Automation-Augmentation Paradox, in: Academy of Management Review, in press. DOI: 10.5465/2018.0072.

15. SCHEER A.W., ABOLHAUSSAN F., JOST W., KIRCHAMERM., 2004, Business Process Automation, ARIS in Practice, Springer, Berlin, Heidelberg.

16. SULMICKI, P., 1973, Planowanie i zarzadzanie gospodarcze, Państwowe Wydawnictwo Ekonomiczne, Warszawa.

17. WORK SERVICE, 2018, Postawy pracodawców wobec automatyzacji pracy, https://www.workservice.com/pl/Centrum-prasowe/Informacje-prasowe/ Ekspert-HR-komentuje/Polacy-nie-powinni-bac-sierobotow-Tylko-co-4-firma-planuje-automatyzacjepracy.

18. UN, 2020, World population projected to reach 9.8 billion in 2050, and 11.2 billion in 2100, https:// www.un.org/development/desa/en/news/population/ world-population-prospects-2017.html. 
